\title{
CONSEQUENCES OF SOCIALISM IN EMPLOYEE'S ATTITUDES
}

\author{
Ruth Alas \\ Estonian Business School. Lauteri 3, Tallinn 10114, Estonia. E- \\ mail: ruth.alas@ebs.ee
}

Received: 29 November, 2002

\begin{abstract}
This paper compares people from former socialist countries with those of non-socialist countries according to their attitudes toward society, trade unions, work and the organisations they work for - based on empirical data from 15 countries. Results indicate that intrinsic factors of job satisfaction in the traditional capitalist countries have a greater correlation with feelings toward the company and general job satisfaction than extrinsic factors. The opposite is true of former socialist countries. Countries with a socialist past have to deal with the satisfaction of needs at a lower level than traditional capitalist countries and this consequently influences attitudes and expectations toward society, trade unions, organisations and work.
\end{abstract}

Keywords. Attitudes; Commitment to the company; Facets of job satisfaction; General satisfaction with work life; Trade Unions; Socialism; Attitudes toward society

\section{Introduction}

In a global business environment it has become particularly important to integrate and develop understanding about fundamental work attitudes in a crosscultural framework. At the same time researchers have found, that it is not possible to generalise even the most commonly researched job satisfaction construct across countries nor identify which job facets contribute to overall job satisfaction in different countries. Additional research is needed $[1,2]$.

For 50 years, Eastern Europe and parts of central Europe were under a socialist regime. This time was long enough to fundamentally influence people's attitudes. Today these countries have passed through a period of transition from a planned economy to a free market economy. These two economic orders are based on different attitudes and values. In the socialist system the most important aim was to provide jobs for all, it did not matter what this person actually did or whether his/her output was necessary at all. The governing systems had not regarded efficiency as the main purpose. However, efficiency in its Weberian sense has always been the primary objective of organisations in both private and public sectors in most Western capitalist democracies.

Despite this transition in society, all the former socialist countries still have a lot to do in order to achieve a welfare level comparable with countries in the European Union (EU). The main problem concerns how to accomplish these changes even faster than EU countries. The key factor here is the employees' commitment to change. A positive correlation has been found between the extent to which efforts to bring about change activate an individual's internal resources and the successful implementation of change [3]. People in former socialist countries bring their previously formed attitudes to organisations, and so operate under different rules. Therefore, the following research question arises. How have socialist politics influenced the attitudes of people from former socialist countries?

Several studies have shown job satisfaction as a contributor and predictor to organisational commitment [4, 5]. Although job satisfaction is one of most widely researched topics in organisational psychology, the find- 
ings arc still contradictory and vary across different social policies and economic contexts in different countries [1]. Also, researchers have found that general job satisfaction and the sum of the facets of job satisfaction are not equal [6]. This makes it worthwhile to continue studying this topic. In this paper the author explores information concerning factors affecting employees' commitment to organisations and factors affecting general satisfaction with work life in countries with different historical backgrounds. Also the expectations of trade unions and society are discussed. A brief theoretical overview is followed by an analysis of the results of empirical research in 15 countries.

\section{The Attitudes of Employees}

Employee attitudes are considered an indicator of the future success of an organisation [7]. Attitude is the psychological tendency that is expressed by evaluating a particular entity with some degree of favour or disfavour [8]. A person's attitudes influence that person to act in one certain way instead of another [9]. Attitudes are formed on the basis of affective or emotional experiences and could be seen as cognitive structures that represent past experience [8]. By reflecting more deeply-held beliefs at the organisational and societal level this enables attitudes to be influenced by the overall cultural context.

In an organisational context such attitudes as commitment and satisfaction, which indicate whether individuals will be affectively connected to an institution or would quit $[10,11]$, are crucial. Commitment attitudes could lead to commitment behaviour, which would in turn influence commitment attitudes [12].

O'Reilly and Chatman [13] define organisational commitment as psychological attachment to the organisation. Meyer and Allen [11] differentiate between affective, continuance and normative commitment. Only affective commitment is considered an emotional reward and primary motive for remaining together [14]. During the implementation of radical change requiring changes to attitudes and values, continuance and normative commitment are not enough, affective commitment is necessary.

Job satisfaction, defined as a pleasurable emotional state resulting from the appraisal of one's job [15], is considered as a combination of attitudes about various aspects or facets of the job, which form the overall job satisfaction construct [16]. Researchers have broken job satisfaction up into extrinsic elements affecting behaviour and intrinsic elements affecting attitudes, beliefs and values. Needs connected to extrin- sic factors need to be fulfilled before one can progress upwards to intrinsic motivators [17]. Based on research into 200 accountants and engineers Herzberg [18] separated hygiene factors and motivators. His classification of factors has been criticised for different reasons, including on the basis of the limited research sample [19] and numerous failed attempts to replicate the study in different countries [1]. Later, authors of comprehensive cross-cultural reviews of research into job satisfaction have divided intrinsic and extrinsic facets of job satisfaction differently: pay and promotion have been considered as extrinsic factors and the work itself, supervision and co-workers are viewed as intrinsic factors [1]. As during radical change, such as the former socialist countries have experienced, a change to people's mindset is necessary [20], intrinsic motivators are the most important for the success of change.

Despite the long history of studies in the field of job satisfaction, researchers have not found a general rule for how facets of job satisfaction form general satisfaction. Changes in the work environment have brought about changes in the nature of work, which has in turn influenced the way attitudes to work have been studied in the social sciences [6]. Also, the role of social environments has been under-emphasised in research into attitude [8]. So, there is a need for additional research to discover which facets of the job satisfaction construct are more important for general job satisfaction and how the broader social environment has influenced the importance of these facets.

\section{Empirical study of employees' attitudes}

\subsection{Methodology and sample}

The author of this article conducted an international study initiated by the Denki Ringo research group (Japanese Electrical, Electronic and Information Union) in Estonian organisations. This was a survey of attitudes in the electronics industry, the third phase of which was conducted between 1999-2001 and covers 15 countries with 5914 respondents. A research partner from each country was requested to select two plants: one producing telecommunications equipment and the other electrical goods for household use. Seven of the countries researched had been under socialist rule during their history. Estonia was the only country that had been a part of the former Soviet Union. In addition the research covered Eastern European socialist countries Poland, Czech Republic, Slovakia and Hungary, Slovenia (from former Yugoslavia) and China. People's attitudes in these countries 
are compared to attitudes in traditional capitalist countries like - the USA, Japan, Finland, France, Italy, Spain, South Korea and Hong-Kong. Respondents from former socialist countries formed $51 \%$ of the sample. The author organised and conducted the survey for two plants in Estonia with 536 respondents.

A standardised questionnaire with 39 items was used in every country. Questions were about the respondents' expectations of society and trade unions, about feelings toward organisations and some other areas. Job satisfaction was measured in two different ways. In the first part of questionnaire there were 15 facets of job satisfaction to evaluate on a five-point scale and later among questions about age and marital status there was a single question about general satisfaction with working life.

In order to find out how socialism has influenced people's attitudes, I compared attitudes from former socialist countries with those of non-socialist countries according to their attitudes toward trade unions, society and the organisation they work for. The comparison of two groups of countries was done by means of the ANOVA test. The factors influencing job satisfaction and organisational commitment were found by using correlation analyses and Linear Regression analyses.

\subsection{Job satisfaction}

Generally, the traditional capitalist countries valued satisfaction with their present work life more $(\mathrm{F}(1 ; 5823)=75.796, \mathrm{p}=.000)$ than former socialist countries. The sum of the facets of job satisfaction was also higher $(\mathrm{F}(1 ; 5842)=33.715, \mathrm{p}=.000)$ in traditional capitalist countries. Two groups of countries are compared in Table 1. Although most of the facets of job satisfaction (working conditions, pay and fringe benefits, promotion opportunities, training and re-training, employment security, equal opportunities for men and women and welfare provision) were statistically significantly higher in the group of traditional capitalist countries, there were some exceptions. For instance, regarding the factor of overtime per month, capitalist countries exceeded ( $\mathrm{M}=22$ hours, $\mathrm{SD}=2.3)$ the corresponding figures of post-socialist countries $(\mathrm{M}=8$ hours, SD-1.4) significantly $(\mathrm{F}(1 ; 3930)=552.194$, $\mathrm{p}=.000$ ). This was also the main cause for greater dissatisfaction with workload among people with a capitalist background $(\mathrm{F}(1 ; 5790)=18.256, \mathrm{p}=.025)$, and with the length of their work time $(\mathrm{F}(1 ; 5786)=113.021$, $\mathrm{p}=.000)$.

Correlation between the question about general job satisfaction and the sum of the 15 facets of job satisfaction was positive and statistically significant $(\mathrm{r}=.475, \mathrm{p}<.01)$. There was a stronger connection between these two variables in the traditional capitalist countries $(\mathrm{r}=.554, \mathrm{p}<.01)$ than in former socialist countries $(\mathrm{r}=.394, \mathrm{p}<.01)$.

The author analysed the results for general satisfaction with work life and facets of job satisfaction by using the Linear Regression analysis. In the analyses, general satisfaction was taken as a dependent variable and the 15 facets of job satisfaction as independent variables.

Linear Regression analysis reveals that the facets of the entire job satisfaction construct predicts general job satisfaction differently in countries with a different history. The standardised coefficients Beta (B), which enable us to predict how the facets forecast general satisfaction, are presented in Appendix 1. In traditional capitalist countries $40 \%$ of the variability in general satisfaction with work life can be explained by reference to the 15 facets of job satisfaction presented in the current study: $\mathrm{R}^{2}=.403, \mathrm{~F}(15,2472)=$ $111.240, \mathrm{p}=.000$. At the same time in former socialist countries only $16 \%$ of the variability in general satisfaction can be explained by reference to the 15 facets of job satisfaction: $\mathrm{R}^{2}=.162, \mathrm{~F}(15,2466)=$ $31.735, \mathrm{p}=.000$.

Correlation between the question about general job satisfaction and the sum of the 15 facets of job satisfaction was positive and statistically significant $(\mathrm{r}=.475, \mathrm{p}<.01)$. There was a stronger connection between these two variables in the traditional capitalist countries $(\mathrm{r}=.554, \mathrm{p}<.01)$ than in former socialist countries $(\mathrm{r}=.394, \mathrm{p}<.01)$.

The author analysed the results for general satisfaction with work life and facets of job satisfaction by using the Linear Regression analysis. In the analyses, general satisfaction was taken as a dependent variable and the 15 facets of job satisfaction as independent variables.

Linear Regression analysis reveals that the facets of the entire job satisfaction construct predicts general job satisfaction differently in countries with a different history.

The standardised coefficients Beta (B), which enable us to predict how the facets forecast general satisfaction, are presented in Table 1.

In traditional capitalist countries $40 \%$ of the variability in general satisfaction with work life can be explained by reference to the 15 facets of job satisfaction presented in the current study: $\mathrm{R}^{2}=.403, \mathrm{~F}(15$, 
Table 1. Facets of job satisfaction affecting employee feelings toward the organisation they work for and general satisfaction with work life

\begin{tabular}{|c|c|c|c|c|c|c|}
\hline $\begin{array}{l}\text { Facets of job } \\
\text { satisfaction }\end{array}$ & \begin{tabular}{|l|}
$\mathrm{SC}$ \\
$\mathrm{N}=2957$ \\
$\mathrm{M}$ \\
$\mathrm{SD}$
\end{tabular} & \begin{tabular}{|l}
$\mathrm{CC}$ \\
$\mathrm{N}=2838$ \\
$\mathrm{M}$ \\
$\mathrm{SD}$
\end{tabular} & \begin{tabular}{|l|}
$\mathrm{FC}$ \\
$\mathrm{SC}$ \\
Beta \\
$\mathrm{N}=2410$
\end{tabular} & \begin{tabular}{|l}
$\mathrm{FC}$ \\
$\mathrm{CC}$ \\
Beta \\
$\mathrm{N}=2384$
\end{tabular} & \begin{tabular}{|l|} 
GS \\
SC \\
Beta \\
$\mathrm{N}=2481$
\end{tabular} & $\begin{array}{c}\text { GS } \\
\text { CC } \\
\text { Beta } \\
\mathrm{N}=2487\end{array}$ \\
\hline $\begin{array}{l}\text { Working } \\
\text { conditions }\end{array}$ & $\begin{array}{l}2,75 \\
1,09\end{array}$ & $\begin{array}{l}2,65 \\
1.10\end{array}$ & ,045 & ,030 & .061 & .025 \\
\hline $\begin{array}{l}\text { Trust between } \\
\text { managers and } \\
\text { employees }\end{array}$ & $\begin{array}{l}2,75 \\
1.00\end{array}$ & $\begin{array}{l}2,75 \\
.99\end{array}$ & ,050 & ,072 & -.001 & .086 \\
\hline Work load & $\begin{array}{l}2.74 \\
, 96\end{array}$ & $\begin{array}{l}2,80 \\
1,00\end{array}$ & -.021 & -.027 & ,050 & .056 \\
\hline $\begin{array}{l}\text { Length of working } \\
\text { time }\end{array}$ & $\begin{array}{l}2,36 \\
, 92\end{array}$ & $\begin{array}{l}2,65 \\
1,06\end{array}$ & -.026 & ,121 & -.018 & , 130 \\
\hline $\begin{array}{l}\text { Pay and fringe } \\
\text { benefits }\end{array}$ & $\begin{array}{l}3,55 \\
1.07\end{array}$ & $\begin{array}{l}3,08 \\
1.10\end{array}$ & , 150 & .034 & .133 & .058 \\
\hline $\begin{array}{l}\text { Competence of } \\
\text { management }\end{array}$ & $\begin{array}{l}2,79 \\
1,02\end{array}$ & $\begin{array}{l}2,82 \\
1,02\end{array}$ & ,002 & 091 & .057 & .024 \\
\hline $\begin{array}{l}\text { Promotion } \\
\text { opportunities }\end{array}$ & $\begin{array}{l}3,41 \\
1,04\end{array}$ & $\begin{array}{l}3,16 \\
1,07\end{array}$ & ,040 & ,018 & ,018 & -.020 \\
\hline $\begin{array}{l}\text { Training and re- } \\
\text { training }\end{array}$ & $\begin{array}{l}3.08 \\
1,09\end{array}$ & $\begin{array}{l}2,94 \\
1,07\end{array}$ & ,035 &,- 023 & -.013 & .003 \\
\hline $\begin{array}{l}\text { Security of } \\
\text { employment }\end{array}$ & $\begin{array}{l}3,04 \\
1,14\end{array}$ & $\begin{array}{l}2,58 \\
1,02\end{array}$ & -.046 & -.007 & .110 & ,067 \\
\hline $\begin{array}{l}\text { Equal } \\
\text { opportunities for } \\
\text { women and men }\end{array}$ & $\begin{array}{l}2,83 \\
1,08\end{array}$ & $\begin{array}{l}2.68 \\
1.03\end{array}$ & .022 & -.011 & .019 & ,013 \\
\hline Welfare provision & $\begin{array}{l}3,20 \\
1.12 \\
\end{array}$ & $\begin{array}{l}2,64 \\
1,02 \\
\end{array}$ & ,040 & .004 & ,052 & -019 \\
\hline $\begin{array}{l}\text { Relationship with } \\
\text { your boss }\end{array}$ & $\begin{array}{l}2,29 \\
.94\end{array}$ & $\begin{array}{l}2,42 \\
1.01\end{array}$ & ,054 & 001 & .047 & ,129 \\
\hline \begin{tabular}{|l|} 
Relationship with \\
your co-workers
\end{tabular} & $\begin{array}{l}1.92 \\
.78\end{array}$ & $\begin{array}{l}2,03 \\
, 81\end{array}$ & -.066 & ,024 & -.009 & ,069 \\
\hline $\begin{array}{l}\text { The extent to } \\
\text { which your work is } \\
\text { interesting }\end{array}$ & $\begin{array}{l}2,41 \\
.93\end{array}$ & $\begin{array}{l}2,43 \\
.97\end{array}$ & .179 & ,162 & .113 & .251 \\
\hline $\begin{array}{l}\text { Business } \\
\text { information } \\
\text { provided by } \\
\text { management }\end{array}$ & $\begin{array}{l}2.91 \\
1.19\end{array}$ & $\begin{array}{l}2,91 \\
1.01\end{array}$ & -.041 & .066 & -.022 & .035 \\
\hline Sum of facets & $\begin{array}{l}2.79 \\
, 62\end{array}$ & $\begin{array}{l}2,70 \\
.66\end{array}$ & & & & \\
\hline $\begin{array}{l}\text { General } \\
\text { satisfaction }\end{array}$ & $\begin{array}{l}2,72 \\
.97\end{array}$ & $\begin{array}{l}2.51 \\
, 91\end{array}$ & & & & \\
\hline $\begin{array}{l}\text { Feelings towards } \\
\text { the company }\end{array}$ & $\begin{array}{l}1,69 \\
.70\end{array}$ & $\begin{array}{l}1.72 \\
, 73\end{array}$ & & & & \\
\hline
\end{tabular}

Notes:

SC - Countries with socialist past

CC - Traditional capitalist countries

FC - Feelings toward the organisation

GS - General satisfaction

General satisfaction was evaluated on a 5 point scale, where T means 'very satisfied' and '5'very dissatisfied'.

'Feelings toward the company' was evaluated on a 4-point scale, where:

1 - 'I would like to put my best effort towards the company's success',

2 - 'I would like to give as much effort to the company as the company gives to me as reward',

3 - 'I do not have much feeling towards the company',

4 - I am indifferent to any matters concerning the company'

Bold notes statistically significant connections, $\mathrm{p}<.05$.
2472) $=111.240, p=.000$. At the same time in former socialist countries only $16 \%$ of the variability in general satisfaction can be explained by reference to the 15 facets of job satisfaction: $\mathrm{R}^{2}=.162, \mathrm{~F}(15,2466)=31.735, \mathrm{p}=$ .000 .

Results from the Linear Regression analysis indicate that in former socialist countries working conditions and welfare provisions predict general job satisfaction, but in capitalist countries they do not (Table 1). In traditional capitalist countries, relationships with coworkers helped to predict general job satisfaction, but in socialist countries they did not.

The analysis indicates differences between countries. In Table 2 facets of job satisfaction are ranked according to their contribution to general satisfaction with work life in both groups of countries.

In the traditional capitalist countries, intrinsic factors like relationships and interesting work contribute more to general satisfaction than in countries with a socialist experience.

The extrinsic factors like pay, working conditions and welfare provision had more importance in former socialist countries than in the others.

Table 2. Facets contributing to general job satisfaction with work life

\begin{tabular}{|l|l|l|}
\hline & Countries with a socialist past & \multicolumn{1}{|c|}{ Traditional capitalist countries } \\
\hline 1 & Pay and fringe benefits & $\begin{array}{l}\text { The extent to which your work } \\
\text { is interesting }\end{array}$ \\
\hline 2 & $\begin{array}{l}\text { The extent to which your work } \\
\text { is interesting }\end{array}$ & Length of working hours \\
\hline 3 & Job security & Relationship with your boss \\
\hline 4 & Working conditions & Trust between managers and employees \\
\hline 5 & Competence of management & Relationship with your co-workers \\
\hline 6 & Welfare provision & Security of employment \\
\hline 7 & Work load & Pay and fringe benefits \\
\hline 8 & & Work load \\
\hline
\end{tabular}

\subsection{Commitment to the company}

There was a positive correlation between satisfaction and commitment to the company. Correlation between satisfaction and commitment to the company was stronger in traditional capitalist countries - the sum of the specific facets of satisfaction being $r=.407$ and general satisfaction being $r=.295$. The same correlation for former socialist countries is $\mathrm{r}=.320$ and $\mathrm{r}=.178$. Any correlation is significant at the level 0.01 .

Although, according to the data in Table 1, there was no significant difference in affective commitment to the company between the two groups of countries $(F(1 ; 5590)=2.713, p=.100)$, there were differences in 
the factors influencing employee commitment to the company. Feelings toward the company were taken as a dependent variable and employee job satisfaction was taken as an independent variable in the Linear Regression analysis. Table 1 presents the standardised coefficient Beta (6). In traditional capitalist countries $20 \%$ of the variability in commitment to the company can be explained by reference to the 15 facets of job satisfaction presented in the current study: $\mathrm{R}^{2}=.204$, $\mathrm{F}(15,2369)=40.554, \mathrm{p}=.000$. In former socialist countries this number is smaller: only $12 \%$ of the variability can be explained by reference to the same facets of job satisfaction: $\mathrm{R}^{2}-.125, \mathrm{~F}(15,2395)=22.731$, $\mathrm{p}=.000$.

Results in Table 3 indicate that feelings toward the company in both blocks of countries depend on the extent to which the work is interesting. At the same time, in countries with a socialist past - pay and fringe benefits, relationships with co-workers and with the boss and also working conditions - play a significant role in employee commitment to an organisation.

In the other block of countries, instead of these factors - competent management, trust between managers and employees, business information provided by the management and length of working hours - significantly influenced employees' feelings toward the company.

In traditional capitalist countries intrinsic factors predict employee commitment to the company better than extrinsic factors. The opposite is true of former socialist countries.

Table 3. Facets contributing to commitment to the company

\begin{tabular}{|l|l|l|}
\hline & Countries with socialist past & \multicolumn{1}{|c|}{ Traditional capitalist countnes } \\
\hline 1 & $\begin{array}{l}\text { The extent to which your work } \\
\text { is interesting }\end{array}$ & $\begin{array}{l}\text { The extent to which your work } \\
\text { is interesting }\end{array}$ \\
\hline 2 & Pay and fringe benefits & Length of working time \\
\hline 3 & Relationship with your boss & Competence of management \\
\hline 4. & Working conditions & Trust between managers and employees \\
\hline 5 & & $\begin{array}{l}\text { Business information provided by } \\
\text { management }\end{array}$ \\
\hline
\end{tabular}

\subsection{Attitudes toward society}

Attitudes among people with a socialist background were remarkably different in regard to the issue of material inequality. Respondents from the socialist block found social differences greater than respondents from traditional capitalist countries $(\mathrm{F}(1 ; 5385)=$ 655.060, $\mathrm{p}=.000$ ). Respondents from Slovakia rated inequality the highest: $67 \%$ of respondents found social differences very high and $37 \%$ considered it ratherhigh. Consequently we could say that $99 \%$ of the population in Slovakia thought their society was unequal. The percentage was higher also in Poland (63\% and $30 \%$ ), Hungary (48\% and $42 \%$ ), Czech Republic (52\% and $42 \%$ ), Estonia (45\% and $41 \%$ ), China and Slovenia: all former socialist countries. At the same time almost half of the respondents in Japan, the USA and Spain consider inequality moderate. We could say that this feature differentiated the countries on the basis of their political past best of all.

We asked the respondents what kind of society they would like. According to the results of the ANOVA test, respondents from former socialist countries valued the following factors more than respondents from traditional capitalist countries: all people are provided with a good material standard of living $(\mathrm{F}(1 ; 5413)=$ 648.439, $\mathrm{p}=.000$ ); social order is well kept with few criminal offences $(\mathrm{F}(1 ; 5389)=84.748, \mathrm{p}=.000)$; and people can live with peace of mind $(\mathrm{F}(1 ; 5390)=$ $66.928, \mathrm{p}=.000)$. In addition wc could also mention one other factor, that people live their life by observing well-established values and ethics $(\mathrm{F}(1 ; 5360)=$ 9.116, $\mathrm{p}=.003$ ). Traditional capitalist countries on the other hand considered the following factors of more importance than the other group did: all people cooperate with each other in solidarity $\left(\mathrm{F}(1 ; 5373)^{\wedge}\right.$ 48.044, $\mathrm{p}=.000$ ); a highly developed social equality among people $(\mathrm{F}(1 ; 5383)=5.043, \mathrm{p}=.025)$; and the individual can develop their life by having a wide range of opportunities $(\mathrm{F}(1 ; 5360)=9.116, \mathrm{p}=.003)$.

\subsection{Attitudes toward Trade Unions}

Research results in Table 4 indicate, that in countries with a socialist experience trade union (TU) membership was lower than in other countries $(\mathrm{F}(1 ; 5506)=$ 44.734, $\mathrm{p}=.000$ ).

Table 4. Trade Union membership and participation in the work of Trade Unions by workers from countries with different histories

\begin{tabular}{|c|c|c|c|c|c|}
\hline TU members & $\begin{array}{l}\text { \%in } \\
\text { SC }\end{array}$ & $\begin{array}{l}\text { \%in } \\
\text { CC }\end{array}$ & TU participation & $\begin{array}{l}\text { \% in } \\
\text { SC }\end{array}$ & $\begin{array}{l}\text { \%in } \\
\text { CC }\end{array}$ \\
\hline Never & 30,1 & 27,2 & Whenever possible & 13,8 & 12,0 \\
\hline Yes, in the past & 23,6 & 11,4 & Often & 16,0 & 16,8 \\
\hline Yes, now & 37.6 & 56,4 & Sometimes & 23,0 & 29.6 \\
\hline Total & 91,3 & 95.0 & Seldom & 25.2 & 24,3 \\
\hline Missing & 8,7 & 5,0 & Never & 21,3 & 14,2 \\
\hline Total & 100,0 & 100,0 & Total & 99.3 & 96,8 \\
\hline
\end{tabular}

Notes:

SC - Countries with socialist past CC -

Traditional capitalist countries

In Japan $100 \%$ of the respondents belonged to a TU, next was Finland with $81 \%$. Spain (where $0 \%$ of employees in the two electronics companies researched 
were TU members) and Estonia (with 5\%) ranked last according to the number of TU members. The number of people, who had given up TU membership, was also significantly higher in countries with a socialist past.

Participation by members of TU injocal union activities was also lower $(\mathrm{F}(1 ; 2708)=6.227, \mathrm{p}=.013)$ in former socialist countries than in traditional capitalist countries (Table 4). If, in capitalist countries $14 \%$ of TU members never participated in local union activities, then $21 \%$ of TU members from the other group of countries never participated in activities.

Respondents were also asked how the decisions made by local unions and managers reflected employees' opinions. Respondents from capitalist countries found that decisions by local unions better reflected their opinions than respondents with a socialistic past $(\mathrm{F}(1 ; 5370)=30.544, \mathrm{p}=.000)$. There was no difference concerning the decisions of management $(\mathrm{F}(1 ; 5730)=2.021, \mathrm{p}=155)$.

Although TU members from both groups of countries found that the most important spheres of activity for a TU involved job security, employment protection and wage increases, there were also some differences. Respondents from traditional capitalist countries put more emphasis on increasing the possibilities for influencing management policies than the other group $(\mathrm{F}(1 ; 2663)=11.269, \mathrm{p}=.001)$. At the same time, respondents from former socialist countries were more interested in company-based welfare facilities and services $(\mathrm{F}(1 ; 2678)=12.202, \mathrm{p}=000)$.

Differences in the areas of satisfaction and commitment were also found between members of trade unions from the different groups of countries. TU members from former socialist countries indicated higher general satisfaction and commitment to the company than non-members. In traditional capitalist countries TU members were less committed and their total for the survey questions about the facets of job satisfaction was lower than for non-members.

\section{Conclusions and discussion}

Results indicate that there are significant differences in the attitudes, toward society, trade unions, organisations and work, held by people in countries with different histories.

Respondents from former socialist countries expected society to provide people with a good material standard of living and a high level of social order with few criminal disorders compared with other countries. At the same time, respondents from traditional capitalist countries were more concerned about co-operation, highly developed social equality and the creation of opportunities for the individual to develop themselves. According to Maslow's [17] hierarchy of needs, the group of countries with a socialist past are basically dealing with survival needs at the two lower levels physiological needs and personal safety. At the same time, the other group of countries have passed these stages already and are dealing with higher level needs in order to create cooperation and conditions for selfactualisation. According to theorists in the post-modern era in order to hold an organisation together, greater attention should be given to creating a strong feeling of solidarity [21]. It seems, that former socialist countries still have a lot to do in order to satisfy survival needs, before higher order needs can take over as motivating forces.

There were significant differences between the two groups of countries concerning participation in the activities of Trade Unions (TU). In countries with a socialist experience TU membership was lower than in other countries and member participation in the work of local union activities was also lower. According to a segmented model of union participation [22], TU members in former socialist countries tend to be "card carriers". This might be the consequence of differences in the level of power enjoyed by a TU in countries with different histories. The research indicated that respondents from capitalist countries found that decisions made by local unions better represented their opinions while respondents from countries with a socialist background were of a different opinion. At the same time there appeared to be no difference concerning respondents' thoughts about the decisions of management. Here the past has exerted a significant influence because within the soviet system trade unions were affiliated with the communist party [23:66] and didn't represent employees' interests in the traditional way. These were, to a large extent, formal organisations to which everyone had to belong. After Estonia gained independence, the system of TU was broken up and as current research indicates, people still don't find TU useful. The opposite effect has been found in the other group of countries: despite a higher level of satisfaction with facets of job satisfaction among workers with a capitalist background, some of the factors were still considered highly important in the work of TU. The reason probably lies with the fact that the present satisfactory terms are the result of TU work.

TU members from countries with different backgrounds also had different expectations concerning the spheres of activities of TU. Respondents from tradi- 
tional capitalist countries put more emphasis on increasing influence over management policies than the other group; and, respondents from former socialist countries were more interested in company-based welfare facilities and services than respondents from traditional capitalistic countries. Again, both groups of countries relate to Maslow's needs hierarchy in the same way as they did for attitudes toward society. As the post-modern worker is considered to be one who looks for meaningful work and personal growth in the work setting [21], we may conclude that employees from former socialist countries haven't achieved this level yet.

As with feelings toward society and TU, feelings toward the company can also be compared using Maslow's hierarchy of needs. The results are similarcommitment to the company in countries with a socialist past can be predicted by lower level needs than in countries without this experience. Commitment to the company in countries with a socialist past is influenced by pay and fringe benefits, relationships with co-workers and the boss and also by working conditions. At the same time in the capitalist countries instead of these factors - competent management, trust between managers and employees, business information provided by the management and length of working hours - significantly influenced employees' feelings toward the company.

Finally, needs were better satisfied and consequently job satisfaction was higher in traditional capitalist countries. Also, in traditional capitalist countries intrinsic factors better predict employee commitment to the company than extrinsic factors. The opposite is true of former socialist countries.

On the one hand, the reasons for differences in all these attitudes may stem from the different developmental stages of the market economy and on the other hand, many of these differences may stem from the existence of different ideologies in the country's past. The time that former socialist countries have had to move from a totalitarian regime to a democratic one has been too short for developing a sufficient level of welfare as the basis for employee self-reliance. Employees arc afraid of losing their job and so find themselves dependent on their manager's will.

Concerning the issue of different ideologies in the past, in totalitarian societies people's choices were constrained because of the use of more coercive forms of political and economic control [8]. On the other hand, in traditional capitalist countries with largely democratic political systems, people are presented with many choices. This difference at the level of society is also carried to organisations. Uksvarav [24:106,118] found that well developed hierarchies, where people expect answers to problems to be decided by someone higher up and even managers were inclined to rely on aid and direction from higher authority, one of the outstanding features of the soviet era in Estonia. On the other hand, although Finnish organisations tended to be more hierarchical than organisations in other Scandinavian or Anglo-Saxon countries, Finnish managers neither needed nor asked the opinion of many people before making decisions [23:60]. Finns enjoy work when authority and responsibility are defined by means of an appropriate goal setting procedure and they are left to get on with their work [ibid:65]. So, when the transition of Estonian society started, employees had a package of working habits and attitudes toward organisational tasks. However, this is somewhat different to the understanding of what organisations need in a market economy.

Theorists have said that the capital (principle resources) of organisations in the post-modern era takes the form of information and expertise, and people providing such resources are often much more influential and expect more intrinsic satisfaction from their work than did workers before the post-modern age [21]. We can conclude from the current study, which compares employees in the electronics industry, that traditional capitalistic countries are mainly dealing with needs characteristic of the post-modern era, but former socialist countries are still struggling at the level of needs that were the main focus during the modernist era. This difference of needs satisfaction has also influenced attitudes and expectations toward society, trade unions and organisations. To make broader conclusions it would also be necessary to test this result in other industries.

\section{References}

1. Judge, T. A., Parker, S. H., Colbert, A. E., Heller, D., \& ilies, R. 'Job Satisfaction: A Cross-Cultural Review', In: Anderson, N., Ones, D. S., Sinangil, H. K., \& Viswesvaran, C. (Eds.) Handbook of Industrial, Work \& Organisational Psychology, 2: 25-52. Organisational Psychology, Sage Publications. 2001.

2. Simonetti, S. H., \& Weitz, J. 'Job Satisfaction: Cross Cultural Effects', Personnel Psychology, 25, 1972, p. 107-118.

3. Jawahar, I. M., Stone, T. H., \& Cooper, W. H. 'Activating Resources in Organisations'. In: Woodman, R. W., \& Pasmore, W. A. (eds.) Research in Organisational Change and Development, 6, 1992, p. 153-196.

4. Johnson, W. R., \& Jones-Johnson, G. 'Differential Predictors of Union and Company Commitment: Parallel 
and Divergent Models', Psychology, 29, 1992, p. 1-12.

5. McNeese-Smith. D. K., \& Nazarey, M. 'A Nursing Shortage: Building Organisational Commitment among Nurses / Practitioner Application', Journal of Healthcare Management, 46(3), 2001, p. 173-187.

6. Brief, A. P. Attitudes In and Around Organisations. Sage Publications. 1998.

7. Hurst, D. K. Crisis and Renewal: Meeting the Challenge of Organisational Change, Boston: Harvard Business School Press. 1995.

8. Eagly, A. H., \& Chaiken, S. The Psychology of Attitudes. Harcourt College Publishers. 1993.

9. Cooper, J., \& Croyle, R. T. 'Attitude and Attitude Change', Annual Review of Psychology, 35, 1984, p. 394-426.

1O.Holton, E. R, III, \& Russell, C. J. 'Organisational Entry and Exit: An Exploratory Longitudinal Examination of Early Careers', Human Performance, 12(3/4), 1999, p. 311-342.

11. Meyer, J. P., \& Allen, N. J. Commitment in the Workplace: Theory, research and Applications. Sage Publications. 1997.

12.Reichers, A. E. 'A review and re-conceptualisation of organisational commitment'. Academy oj management Review, 12, 1985, p. 278-287.

13. O'Reilly, C. A., \& Chatman, J. 'Organisational commitment and psychological attachment: The effects of compliance, identification, and internalisation on pro-social behaviour'. Journal of Applied Psychology, 71, 1986. p. 492-499.

14.0'Malley, M. N. Creating commitment: How to attract and retain talented employees by building relationships that last. John Wiley \& Sons, Inc. 2000.
15. Locke, E. A. 'The nature and causes of job satisfaction'. In Dunnette, M. D. (Ed.) Handbook of Industrial and Organisational Psychology, p. 1297-1343. Chicago: Rand McNally. 1976.

16. Spector, P. E. Job Satisfaction: Application, Assessment, Causes, and Consequences. Sage Publications. 1997.

17. Maslow, A. H. Motivation and personality. New York: Harper \& Row. 1954.

18.Herzberg, F., Mausner, B., \& Synderman, B. The Motivation of Work, New York: John Wiley \& Son. 1959.

19. Weiss, J. W. Organisational Behaviour \& Change: Managing Diversity, Cross-cultural Dynamics, and Ethics. West Publishing Company. 1996.

20. Sathe, V., \& Davidson, E. J. 'Toward a new conceptualisation of culture change'. In: Ashkanasy, N. M., Wilderom, P. M., \& Peterson, M. F. (Eds) Handbook of Organisational ( ulture \& Climate, 2000, p. 279-296.

21. Bergquist, W. The Post-modern Organisation: Mastering the Art of Irreversible Change. Jose-Bass Publisher. 1993.

22. Flood, P., Turner, T, \& Willman, P. 'A Segmented Model of Union Participation'. Industrial Relations, 39(1), 2000, p. 108-118.

23.Nurmi, R., \& Uksvarav, R. 'Estonia and Finland: Culture $\mathrm{h}$ and Management, a Conceptual Presentation', Publications of the Turku School of Economics and Business Administration. Series A-9. 1994.

24. Uksvarav, R. 'Management Culture in Estonia: Past and Present Features', in Suominen, A. (Ed.) Searching for the Boundaries oj Business Culture, Publications of the Turku School of Economics and Business Administration. Series C-1, 2001, p. 103-120. 